\title{
$[4]$
}

\section{At Home, No Womens Are Storytellers: Ceramic Creativity and the Politics of Discourse in Cochiti Pueblo}

\section{Barbara A. Babcock}

The primitive woman has no choice, and, given the duties that go with marriage, is therefore seldom able to take much part in public life. But if she can be regarded as being at a disadvantage in this respect from our point of view, she does not regard herself as being at a disadvantage, and she does not envy her menfolk what we describe as their privileges. She does not desire, in this respect, things to be other than they are.

-E. E. Evans-Pritchard, "The Position of Women in Primitive Societies"

The world man actually lives in, in the sense of his inescapable necessities and the inevitable conditions of life always bulks very small in relation to the world he makes for himself.

-Ruth Benedict, "Magic"

Since the late 1960s, Helen Cordero, a Cochiti Pueblo woman who learned to make pottery at the age of forty-five, has changed the nature

This chapter first appeared as "At Home, No Womens Are Storytellers: Potteries, Stories, and Politics in Cochiti Pueblo," Journal of the Southwest 30 (Autumn 1988); reprinted with permission. 
of Pueblo ceramics (Figure 4.1). When Helen modeled the first "Storyteller" doll in 1964, she made one of the oldest forms of Native American self-portraiture her own, reinvented a long-standing but moribund Cochiti tradition of figurative pottery, and engendered a revolution in Pueblo ceramics comparable to those begun by Nampeyo of Hopi and Maria of San Ildefonso-a revolution that has reshaped her own life as well as that of her family and her pueblo, not to mention the fortunes of innumerable other Pueblo potters (Figure 4.2). ${ }^{1}$ She is not, however, without ambivalence about the consequences of her creativity: See. I just don't know. I guess I really started something. I guess I'm a big Indian artist. But, she hastens to add, I don't like to be called famous. My name is Helen Cordero. It's my grandfather, he's giving me these (Figure 4.3). ${ }^{2}$ But, like it or not, Helen, like her grandfather, Santiago Quintana, who was Ruth Benedict's favorite teller of Cochiti tales, is one of those "gifted individuals who have bent the culture in the direction of their own capacities" (Benedict 1932: 26).

I first met this indefatigable women who is always in a hurry on a June afternoon in 1978. Fascinated by the Storyteller dolls then becoming popular, I had finally screwed up my courage and driven to Cochiti Pueblo to talk with the inventor herself. That particular day Helen was having a new hardwood floor laid in her pottery room so we sat outside under a cottonwood tree. After we had talked for over an hour about her potteries, her patrons, and her grandfather, she asked me why I was asking her all these questions. I replied that I was thinking about writing an article about Storyteller dolls and without hesitation she responded: There are three books about Maria [the famous potter of San Ildefonso Pueblo] and none about me. Thus began a complicated and important relationship that has redefined my life and my work. The difficulties as well as delights that Helen and I have had gathering all these words and pictures together into a big book about her art and experience have convinced me that representing another woman is a problematic enterprise. Betwixt and between Cochiti Pueblo, museum archives, and the world of dealers and collectors who traffic in Indian art, I have been forced to rethink and revise many assumptions about women's art and creativity, about feminism and crosscultural inquiry, about biography, autobiography, and life history, and about the meaning of things.

When after talking with Helen and many other Pueblo potters who have imitated her invention, I began reading scholars in an attempt 


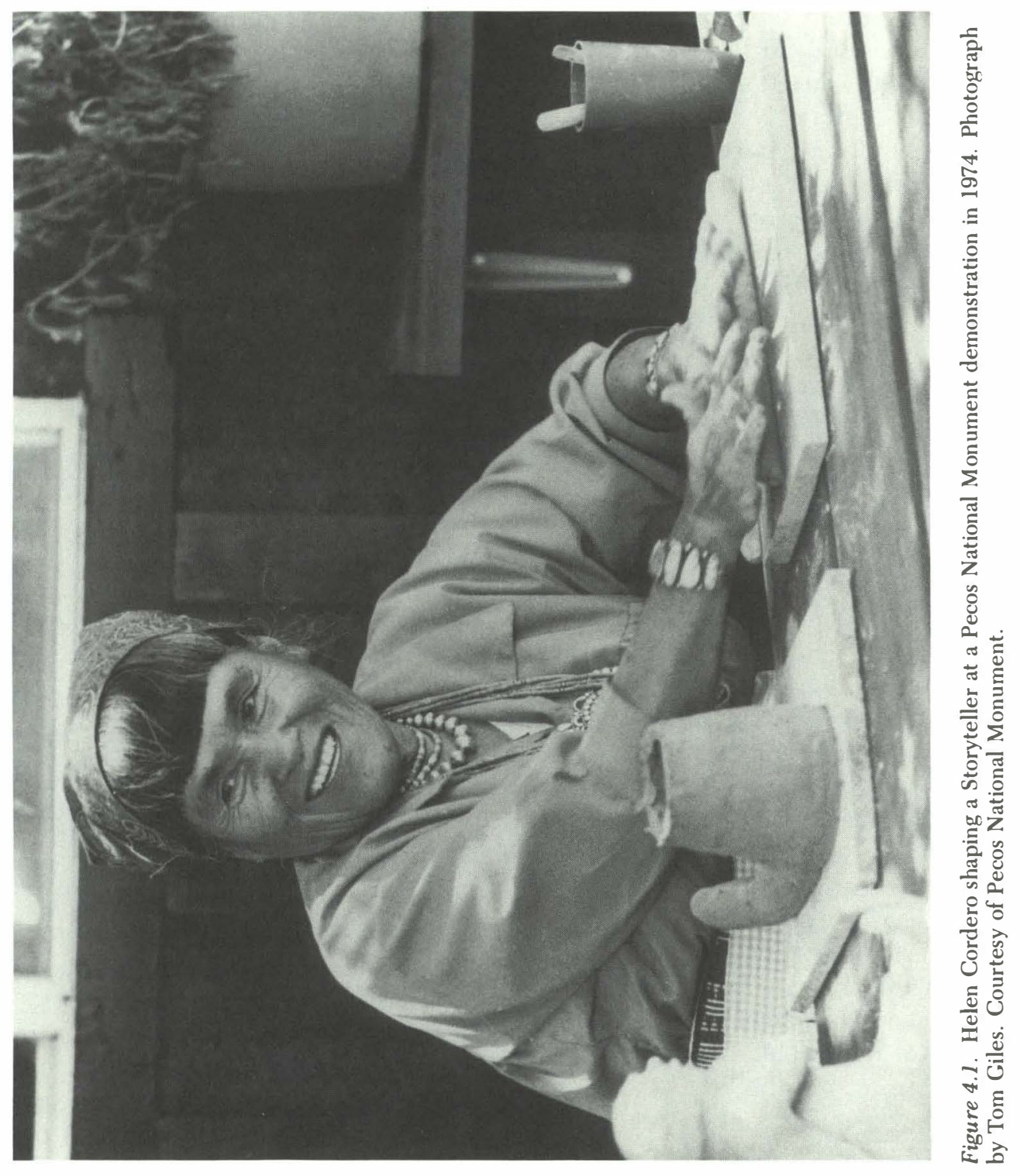




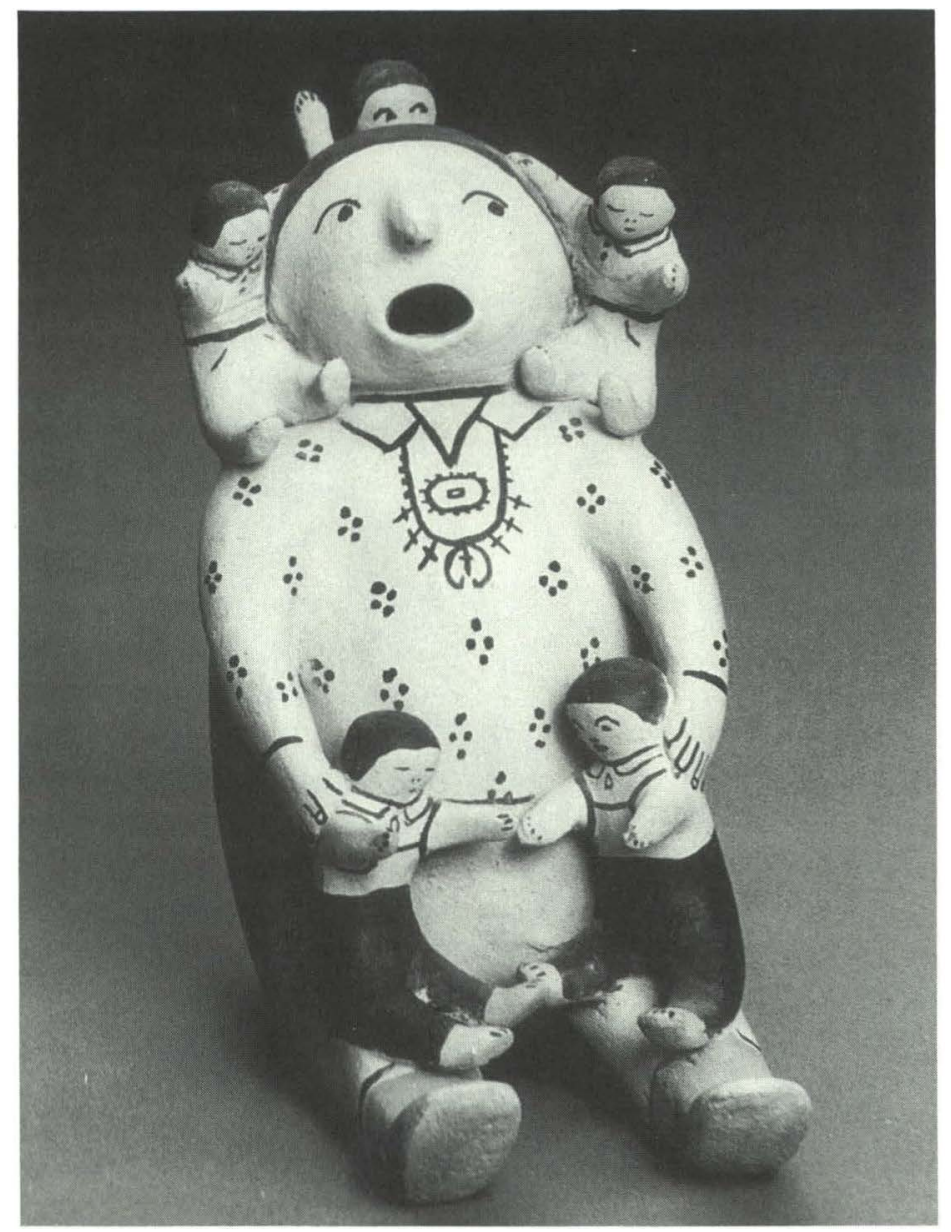

Figure 4.2. The first Storyteller shaped by Helen Cordero in 1964. 8 inches high. Courtesy of the Museum of International Folk Art, Museum of New Mexico, Acc. no. A.79.53-41. Photograph by Glenn Short. 


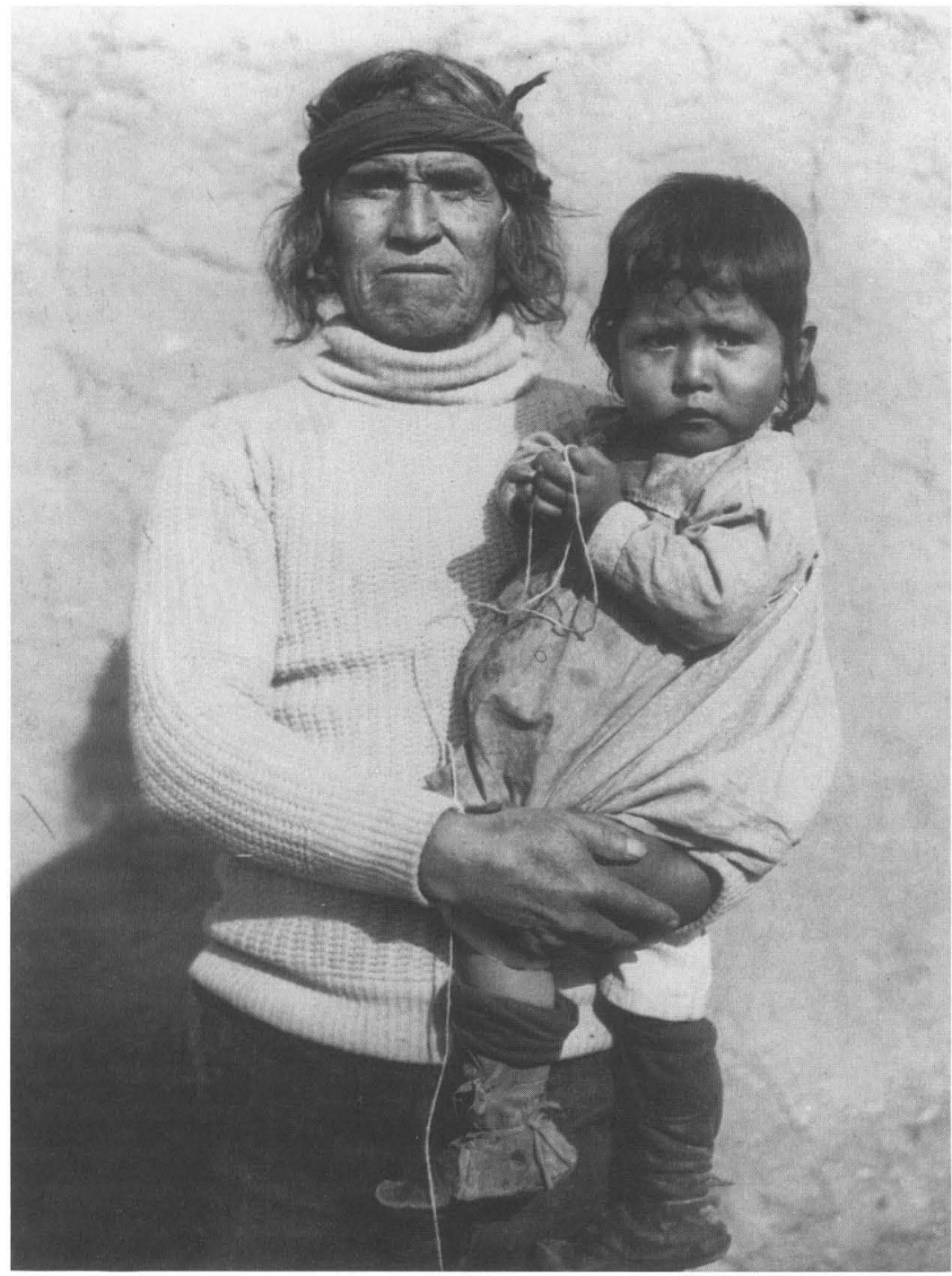

Figure 4.3. Santiago Quintana with one of his many grandchildren. Cochiti Pueblo, ca. 1906. Photograph courtesy of the National Anthropological Archives, Smithsonian Institution, Neg. no. 80-5499. 
to understand the dynamics of this revolution in contemporary ceramics, I discovered that, for the most part, discussions of innovation in ethnic and tribal arts have followed an art historical approach, examining the creativity of the artist or performer in relation to the tradition he or she has inherited, and the subsequent changes his or her work has wrought in the aesthetic system (Biebuyck 1969). In contrast to modern Western art, primitive and folk art is generally regarded as subservient to tradition and community values; the assumption that such "art forms reinforce the bonds of the community rather than make manifest and challenge the oppositions within it" is rarely questioned or examined (Firth 1966: 167). Less frequently and more recently (d'Azevedo 1973), innovation has been interpreted from a psycho- or sociobiographical perspective, that is in relation to the life history and motivations of the innovator and the ways in which he or she is already "marginal," "deviant," etc. Unfortunately, this necessary corrective to the myth of anonymous, collective, traditionbound creativity tends toward a romantic reification of the alienated genius, which says a great deal more about how "we" regard the creative person than about how "they" do. That is beginning to change as scholars move away from these extremes to examine the dialectic of creativeness and constraints, the sociocultural consequences of, and the conditions for creativity, and the politics as well as the poetics of innovation. ${ }^{3}$ In insisting on the inseparability of the poetic and the politic, of artistic innovation and social innovation, I am indebted to both Ruth Benedict and Victor Turner, who opposed the separation of the social and the symbolic and the related separation of science and humanism in anthropological analyses. Rather, they insisted on culture as creative process - and on the ways in which performers and performances (verbal, dramatic, or artifactual) not only follow but revise and revitalize accepted rules, acting out and challenging aesthetic conventions and social values. ${ }^{4}$

More than simply reflecting or expressing social structure and worldview, any significant new form reconstructs cultural reality, causing a dislocation in the economy of cultural representations: "A work of art does not substitute, but institutes an original awareness of existence, on the whole; it does not so much reproduce and represent as produce and present a total experience" (Kaufmann 1969: 147). The Storyteller doll as conceived and realized by Helen Cordero not only "materializes a way of experiencing" and "brings a particular cast of mind out into the world of objects, where men can look at it" (Geertz 1976: 1478), 
but comments on and expands the premises of Pueblo existence. When Helen Cordero re-created her grandfather in clay, it was one of those "fecund moments" when an artist discovers a structure for her sensibility and experience that "makes it manageable" for herself and "at the same time accessible to others" (Merleau-Ponty 1964: 169). It is, therefore, "in the tenor of its setting," in the discourse that surrounds it, that I have looked for both the sources and the consequences of the powerful generative image that she created, asking, to paraphrase Roy Wagner, how is Helen Cordero's invention related to a Cochiti woman's perception of herself and her world? ${ }^{5}$

All innovation involves a dialectic between convention and invention, and when Helen Cordero began making little people over twenty years ago, she continued-with a difference-a centuries-old ceramic tradition. For over a thousand years, Puebloan potters have shaped the clay of the Southwest into representative human and animal forms as well as utility ware. The majority of prehistoric, anthropomorphic figurines are female, and on the basis of contextual archaeological evidence as well as ethnographic data from the past century, archaeologists have conjectured that the Pueblo figurine complex was associated with reproductive ritual — both agricultural fertility cults and rites of human increase ${ }^{6}$ Historic figures such as the mother and child effigy made at Cochiti over one hundred years ago would seem to confirm these connections (Figure 4.4). Her dress is painted front and back with corn plant designs, and here, as throughout Pueblo ritual and religion, the combination of painted and modeled design makes explicit the relationship between human reproduction and other lifegiving forms of generation, especially corn. ${ }^{7}$ The most sacred of all ritual objects is a perfect ear of corn (i'ariko at Cochiti), decorated with beads and feathers, and addressed as "Our Mother" (Parsons 1939: 182, 319-23).

As the Anglo presence increased with the coming of the railroads to New Mexico in the 1880s, the production of figures such as this markedly decreased. Pueblo potters did not, however, hesitate to capitalize on the growing tourist market, and, in addition to bowls and jars, Cochiti women made for sale an abundance of small, desacralized human and animal figures. Anglos bought and sold countless "curiosities," "idols," or "monos," but did not regard them highly or, with the exception of Santa Fe dealer Jake Gold, encourage their production. In the first half of this century, pottery production at Cochiti, as in many other pueblos, declined. As Helen Cordero has 


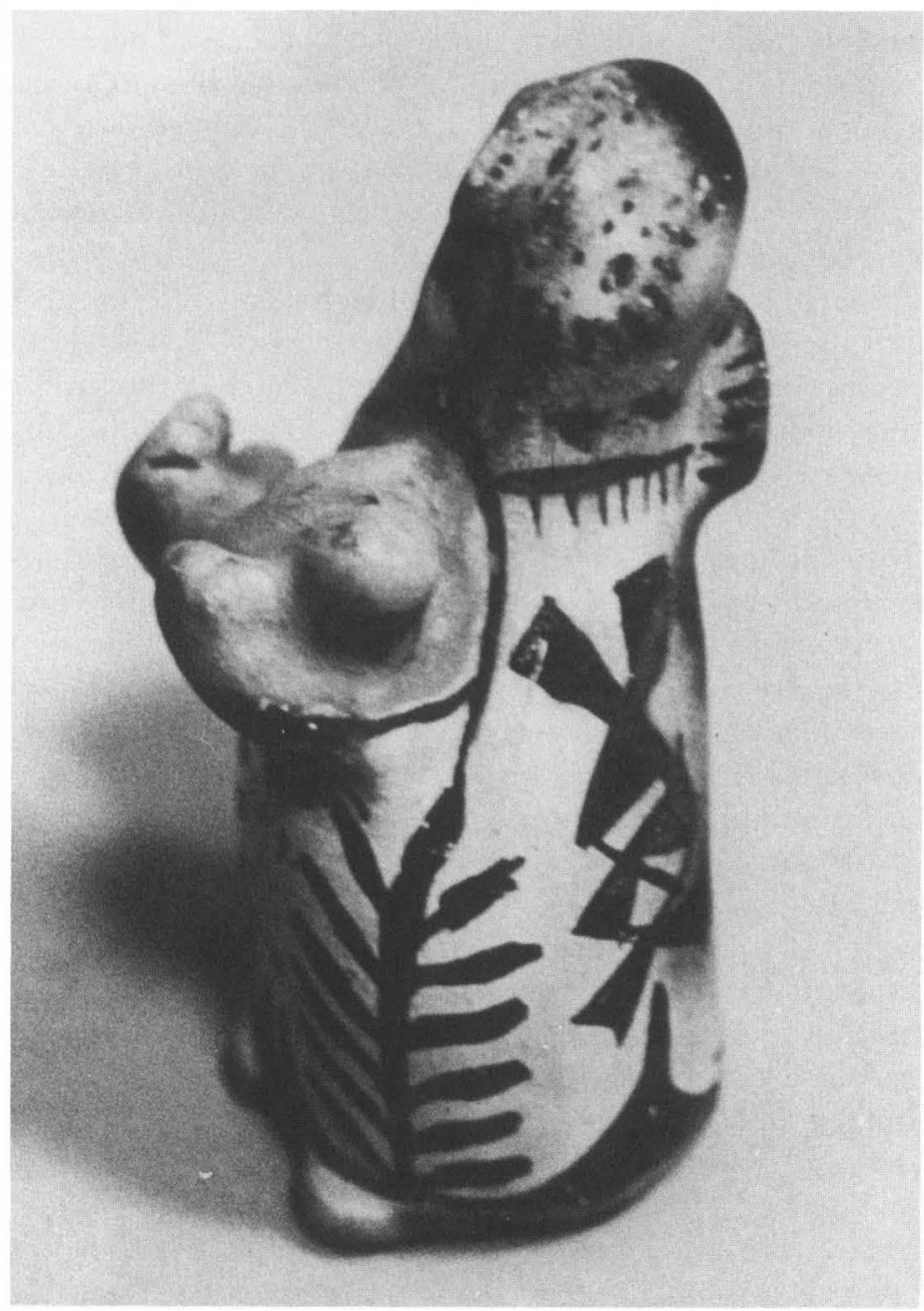

Figure 4.4. Mother and Child Effigy. Artist unknown. Cochiti Pueblo, 1875-80. 7 inches high. This small polychrome figure, collected by Rev. Sheldon Jackson in the late 1870s, is the earliest known Cochiti Singing Mother. Courtesy of the Princeton University Museum of Natural History, Acc. no. P.U.7557. Photograph by J. Bradley Babcock. 
said, For a long time pottery was silent in the pueblo. Nonetheless, this ancient tradition endured, and among those few figurative forms that continued to be made, the image of a woman holding or carrying a child, or a water jar, or a bowl of bread was the most popular. In the decade before Helen Cordero started up on little people, at least three Cochiti potters were still making these singing ladies, singing mothers, or madonnas (Figure 4.5).

By the late 1950s, the six children that Helen had raised were grown, and like other Cochiti women, she began doing bead and leatherwork to make a little extra money. Unfortunately, most of the profits went for buying more materials, and one day Fred Cordero's aunt, Grandma Juana, asked, Why don't you girls go back to potteries? You don't have to buy anything. Mother Earth gives it all to you. And so, Helen started on pottery with her kinswoman Juanita Arquero, who had learned to make pottery as a child, and spent six months under her. Her bowls and jars were all crooked and she despaired of ever getting it right. Juanita suggested that she try figures instead and it was like a flower blooming. She began with little animals, but was soon shaping countless small standing and seated figures, many of them continuing the Cochiti tradition of pottery mothers and children (Figure 4.6). One of the first times Helen showed them out at a Santo Domingo feast day, folk art collector Alexander Girard bought all that she had and asked her to make more and larger figures and bring them to his home in Sante Fe. The first Storyteller (Figure 2) was made in response to his request for a larger seated mother with more children. Helen recalls, When I went home and thought about it, I kept seeing my grandfather. That one, he was a really good storyteller and there were always lots of us grandchildrens around him.

In addition to telling stories to his many grandchildren and being esteemed in the pueblo as a gifted storyteller, the leader of one of the clown societies, a "mucho sabio," and the most powerful of the principales (the tribal council), Santiago Quintana (Figure 4.3) was the valued friend and collaborator of several generations of anthropologists and observers of Cochiti life: Adolph Bandelier, Frederick Starr, Charles Saunders, Edward Curtis, and Ruth Benedict, who collected many of the Tales of the Cochiti Indians (1931) from him and wrote warmly of her "old man" in letters from the field. ${ }^{8}$ When Helen Cordero remembered her grandfather's voice and shaped that first image of him telling stories to five grandchildren, she made two significant modifications in the "singing mother" tradition: (1) she made the pri- 


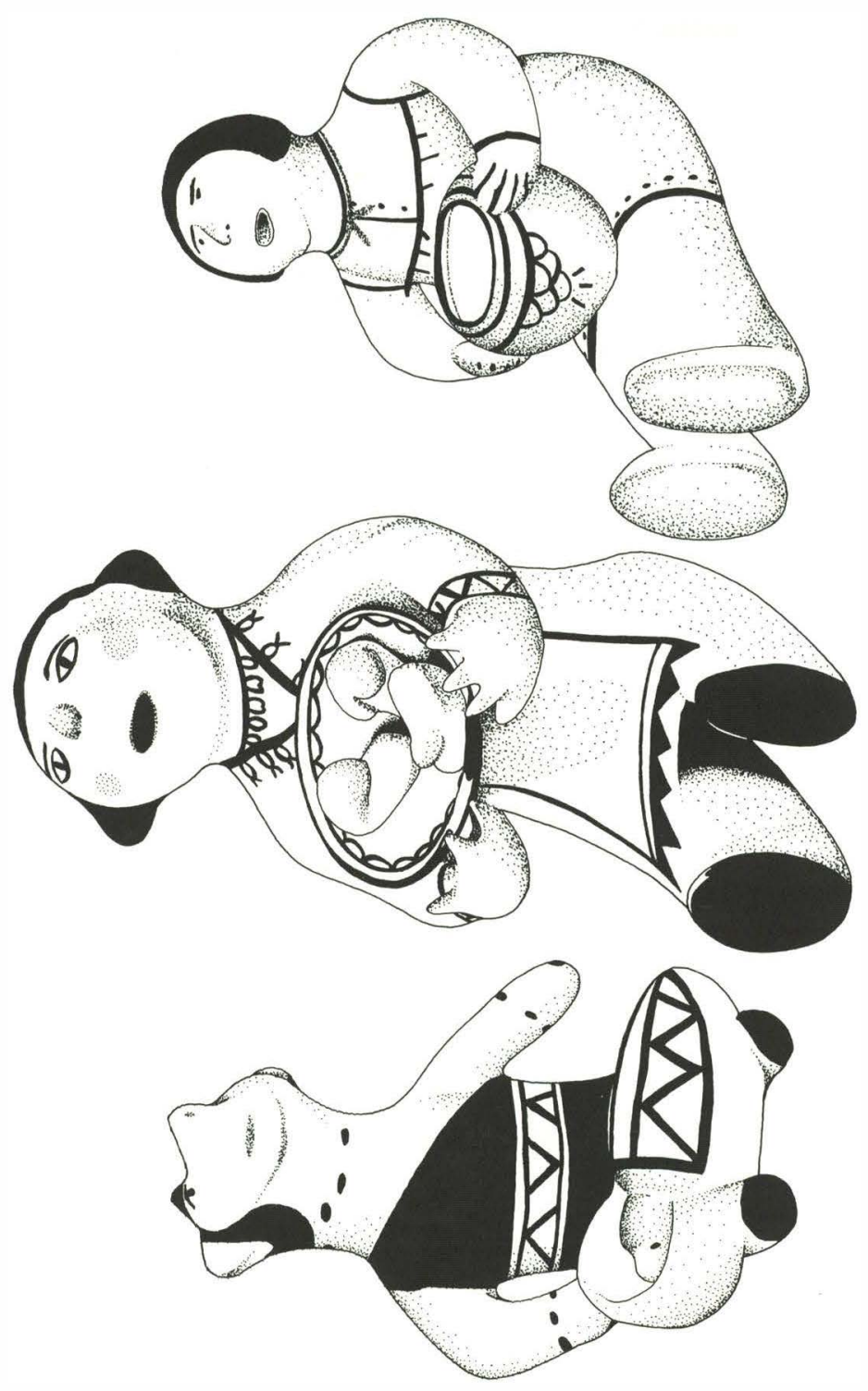

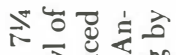

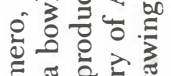
ख

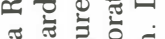

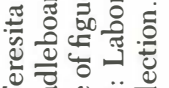

‥ 웡

कि $\approx 20$

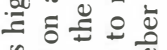

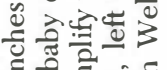

을

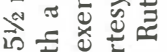

ค

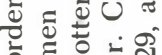

ن ญ

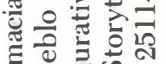

हึँ

คิ

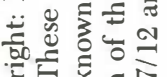

F亲

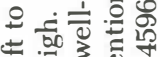

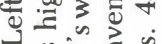

월ㄹㄹ

ญ

ถู 6 บ

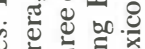

氙造造

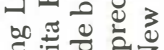

हूँ

ऊิ

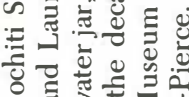

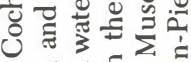

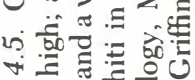

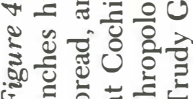




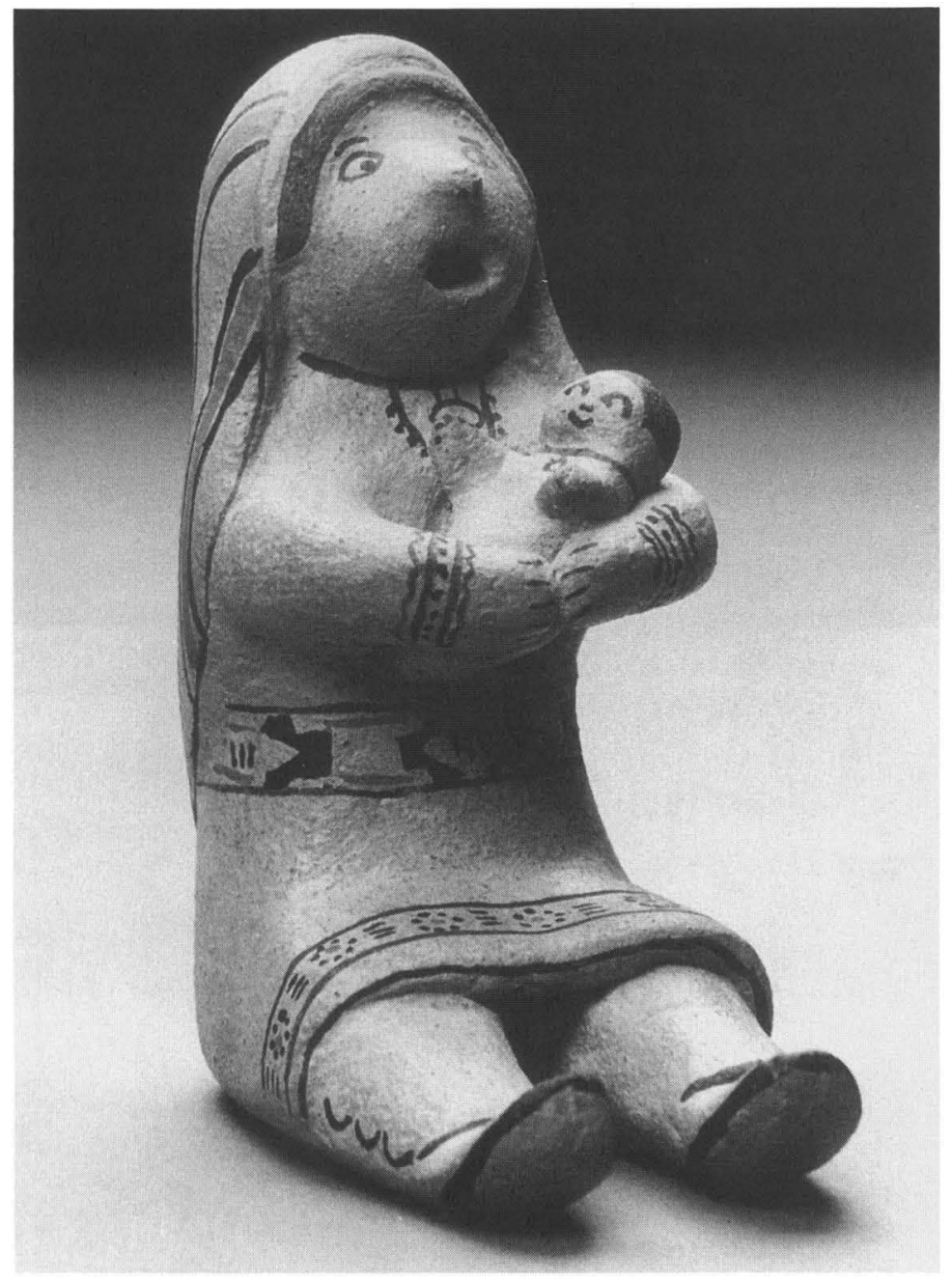

Figure 4.6. Singing Mother. Helen Cordero. Cochiti Pueblo, 1960-61. 51/2 inches high. This figure, characteristic of many small figures Helen Cordero made between 1959 and 1963, is very similar to those made by other Cochiti potters between 1920 and 1960. Marjorie Lambert Collection. Photograph by Glenn Short. 
mary figure male rather than female, and (2) she placed more than a realistic number of children on him. In addition to embodying this dialogic relationship between convention and invention, Storytellers are obviously "about" relationships-between generations, between past and future, and between stories and potteries (Figure 4.7). ${ }^{9}$ Less obviously, Helen's figures in particular are about the relationship between male and female creativity and the reproduction of the cultural order, for her reinvention of this important mode of cultural production and tradition of representation-pottery-making-controlled by women transformed an image of natural reproduction into a figure of an important mode of cultural reproduction-storytelling - that is controlled by men and both embodies and expresses generativity.

From the body of the Storyteller sprout countless children and grandchildren, and from his open mouth emerges "life for the people" in the shape of stories, testifying yet again to Pueblo culture's instinct for survival and its capacity to revitalize itself. ${ }^{10}$ Whether one looks at Pueblo worldview and its dynamics of cultural survival from the perspective of religion, kinship, pottery-making, or narrative traditions, one finds that Pueblo identity and individual and social integration are conceived in terms of fertility and regeneration: "One story is only the beginning of many stories" (Silko 1981: 56); clay images of domestic animals are blessed and buried in the corral "so that there will be more of them" (Parsons 1919: 279) and corn, "the seed of seeds," multiplies itself many times from a single grain (Cushing 1920: 54). The history of the Storyteller is itself an expression of this reproductive dynamic, for the first one was the beginning of countless little people. Helen herself has made more Storytellers and won more prizes than she can or will count-it's like breads, we don't count (Figure 7). By 1973, when the "What Is Folk Art?" exhibit was mounted at the Museum of International Folk Art in Santa Fe, the success and popularity of the Storyteller was such that at least six other Cochiti potters had imitated her invention (Figure 4.8). A decade later, no less than fifty other Cochiti potters and over a hundred potters throughout the New Mexico Pueblos were shaping Storytellers and related figurative forms. Many of these imitations are female figures, and as far as Helen is concerned, they are empathically not really Storytellers. They call them Storytellers, but they don't know what it means. They don't knowit's after my grandfather. At home, no womens are storytellers! ${ }^{11}$

In the six years that I have known Helen, I have repeatedly heard her insist upon both the ancestral and the masculine attributes of her 


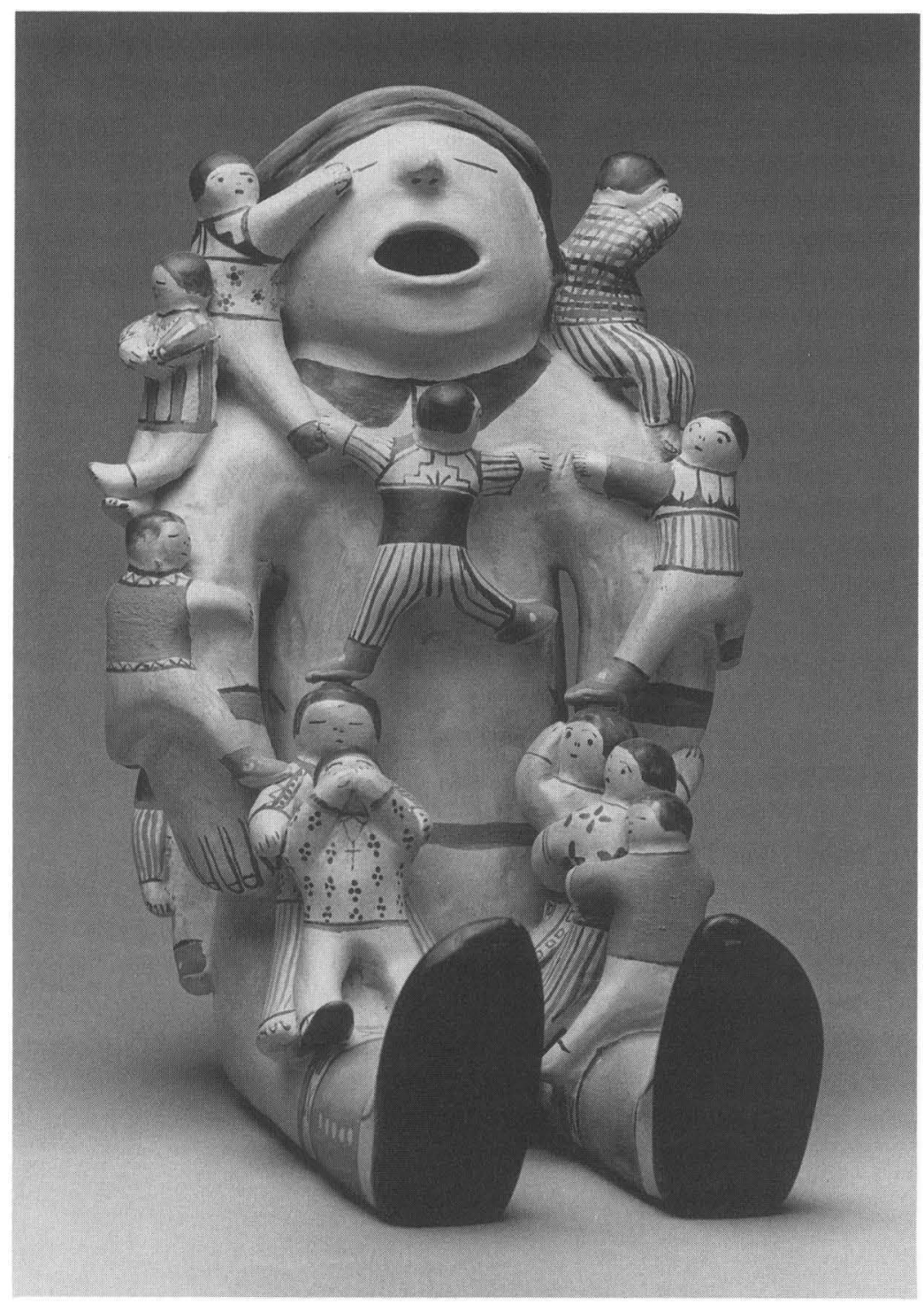

Figure 4.7. Storyteller. Helen Cordero. Cochiti Pueblo, 1971, 121/2 inches high. This Storyteller with 17 children took first prize at the 1971 Santa Fe Indian Market. In 1976, it was featured on a poster printed by the collectors for Helen's one-woman show at the Heard Museum in Phoenix; in 1982, it appeared on the cover of National Geographic. Collection of The Hand and the Spirit Crafts Gallery, Scottsdale, Arizona. Photograph by Glenn Short. 


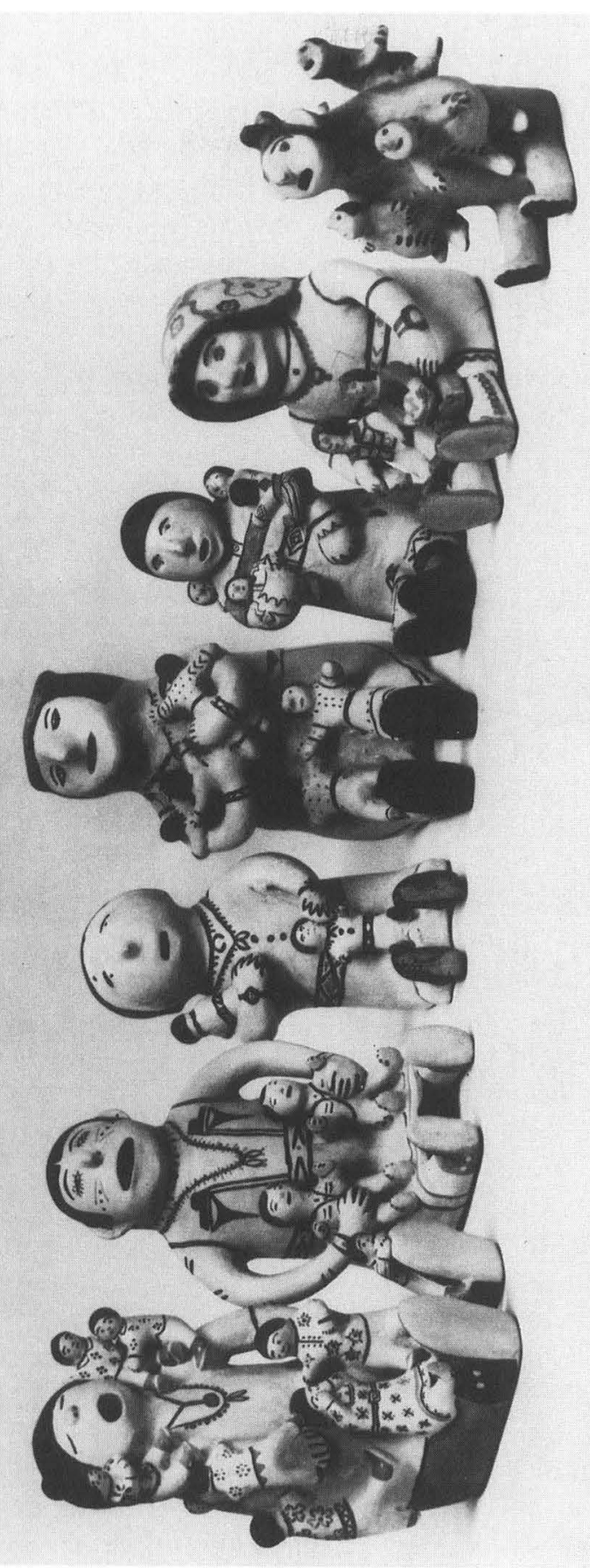

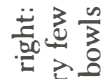

원

눙

¿

ต

ธิ -

을

诖

폰

कึ

过

记

오 홍

万ิ

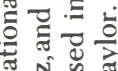

ํํㄹ

壱

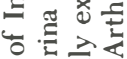

ह 总

ڤ

政

$\sum . \tilde{\Xi}$

o क ते

I

可

돈

শ원웅

$\hat{2}$

넌인

일

흔

玒

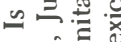

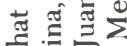

के 3

萧 Z

\pm एٓ

$\Xi$ 安

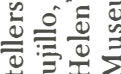

त目公。

옹

응

E记

०००

U范

$\infty$ 닌

$\forall ن \stackrel{0}{=}$

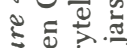

这正总 
figures. Given the fact that both she and her mother (who was Esther Goldfrank's principal informant) tell stories, and that half of Ruth Benedict's narrators were most assuredly female, why this assertion that appears to contradict observed "fact"? And, why, I have asked much more recently, given the obvious economic benefit to the pueblo, did one of its officers try to persuade the tribal council to forbid the well-known Cochiti Storyteller potters-all of whom are women-from having exhibits of their work and from giving potterymaking demonstrations at museums and national parks?

I would like to suggest that these two questions are not unrelated and that answers to them provide clues as to the local significance of Helen Cordero's creativity and to the generative, transformative, and dangerously liminal power of the image she invented. It seemed very strange indeed that in the summer of 1982 the all-male tribal council would have debated whether women potters should demonstrate the making of Storytellers to Anglo tourists when extra income was sorely needed to support summer ceremonials and when Pueblo pottery has been made for an Anglo market for over a century. The more I considered this "social drama," the more entangled I became in a complicated situation involving the politics of reproduction and issues of discourse and authority - of who has the right to represent what to whom. Crises initiate reflexivity and this one forced me to realize that I had naively assumed-as have other scholars of Pueblo ceramicsthat pottery and politics have nothing to do with each other. As I contemplated conflict and clay, I began to see that Storytellers as conceived and invented by Helen Cordero were not just pretty thing made for money in terms of personal identification (All my potteries come from my heart. They're my little people, ) but were to be understood in terms of the degree to which they resist and revise discursive constraints. $^{12}$

When Helen Cordero insists upon the ancestral and masculine attributes of her Storyteller, she is doing much more than emphasizing the difference and uniqueness of her potteries. She is both explicitly and implicitly "authorizing" her creation. Explicitly, by invoking ancestral authority and power: It's my grandfather, he's giving me these. He was a really wise man. He had lots of stories and lots of grandchildrens, and we're all in there, in the clay. ${ }^{13}$ Implicitly, by insisting on the masculinity of her composite figure, and so identifying her pottery with a sacred, masculine activity - a tradition that is both patriarchal and genealogical. Women do tell stories at Cochiti, but 
they do not tell the stories-the master fictions by which the people live. As Parsons (1939: 40) and many other Pueblo scholars have pointed out, men and women have differential access to sacred discourse. Origin myths and legends as well as songs and drums and kachinas and kivas and all the other aspects of sacred discourse, including the ceremonial Keresan in which it is spoken, are controlled by men. As Helen's uncle, Joe Trujillo, remarked several decades ago, “Our kivas are like-how you say in English? Yes, like men's clubs. The women are only admitted for certain ceremonies, but most of the time we men are there alone. Religion is man's business with Indians" (Mason 1948: 85).

If women are practically peripheral, they are symbolically central to this "man's business" which involves, among other things, a transcendental appropriation of the female principle. Pueblo religion is elaborated around the idea of fertility and is indigenously described as a vast, interconnected symbolic web at the center of which sits Spider Woman, Thought Woman, the "mother of all" (Parsons 1939: 192-93). Not surprisingly, the practice of religion involves both comic and serious female impersonation. The cacique, or religious leader of the pueblo, whose chief functions concern rain and fertility and the well-being of his "children," is not only regarded as the representative of Iyatiku, the Corn Mother; he is, after he is installed in office, symbolically viewed as a woman and referred to in female terms. ${ }^{14}$ The cacique is responsible for the spiritual and physical welfare of the pueblo and he "takes care of his people by looking after 'his children' just as the Mother (Iyatiku) whom he represents looked after the images in her basket" (Parsons 1939: 336). In Keresan emergence narratives, Spider Woman sends Iyatiku ("bringing to life") and her sister Nao'tsiti ("more of everything in the basket") up into the light, to this earth with baskets crammed full of seeds and little clay images and sacred cornmeal with which they create and pray into being all forms of life. ${ }^{15}$ The continued association of clay figures with the creation, maintenance, and reproduction of Pueblo life is this practice of collectively representing Keresan townspeople in male and female clay images which are kept and cared for by the cacique.

If Iyatiku's clay figures are regarded as the embodiment of "life for the people," so too are the stories about Iyatiku that are kept and told by men such as Helen's grandfather. Both sacred and secular stories were and are one of the primary modes in which the family, the clan, and the community regenerates itself, for such narratives both describe 
and create "chains" linking generation to generation and back again, and involve what Silko describes as the vital dynamic of "bringing and keeping the people together" (1981: 59). ${ }^{16}$ In the words of contemporary Keresan storytellers, Leslie Silko and Simon Ortiz, "you don't have anything if you don't have the stories" (Silko 1977: 2) and "the only way to continue is to tell a story and there is no other way" (Ortiz 1977: 9). What is remarkable about these stories, past and present, oral and written, is that the idea of fertility and the model of reproduction is re-presented again and again-in the language of and about the stories, in their content, and in the embedded style in which they are structured and told. Nowhere is this more manifest than in the images of a grandfather storyteller, his belly full of "life for the people," giving birth to both children and stories that Leslie Silko and Helen Cordero have created in words and in clay. (See, e.g., Figure 4.8 and Silko's title poem in Ceremony, 1977: 2.)

Both cosmologically and socially, the Keres world is constructed of a series of oppositions of which male vs. female is primary. ${ }^{17}$ Given the facts that woman is ideologically and symbolically central, that clans are matrilineal, and that residence was traditionally matrilocal at Cochiti, it has been fashionable, if not doctrinaire, to describe the distribution of power as complementary and to ascribe to women much more "real" power than they in fact have.$^{18}$ Once upon a time, a Cochiti child received his social identity and physical place from his father. ${ }^{19}$ But times have changed, and while a child is still of his mother's clan and clans still fulfill a nurturant function, Cochiti clans and "clan mothers" are far less important and powerful than they once were. ${ }^{20}$ Wage labor, increased prosperity, and government housing have virtually abolished matrilocal residence-a man who wants his own house builds it. If one's livelihood does not depend on one's fields, the fact that one's wife "owns" them matters little. And with Catholicism in the Rio Grande Pueblos came absolute monogamy, greatly increasing a man's status in the household and his power over his wife. ${ }^{21}$ At the same time, the two kiva organizations or moieties-Turquoise and Pumpkin - are larger and more powerful than ever, and they are patrilineal. Upon marriage, women become members of their husband's kivas and assume the role of "helpers"; children take their father's surname and belong to his kiva. Today, kiva membership is a much more significant determinant of Cochiti social identity than clan affiliation.

Man's business at Cochiti is political as well as religious, for the 
Pueblo government is a theocracy. Supreme power resides with the cacique and the heads of the three medicine societies who annually choose the six major secular officers-governor and lieutenant governor, war captain and lieutenant war captain, and fiscale and lieutenant fiscale-who belong in equal numbers to the two kivas and who become members of the tribal council for life. While the governor controls secular affairs and the fiscale manages the Catholic church, the war captains, who represent the mythic twin war gods, are the "ceremonial police," whose principal duties are preserving traditions and secrets, and leading the fight against tribal enemies. ${ }^{22}$

In sacred discourse and religious practice, in social and political organization, and in domestic and family situations, the relationship between the sexes is a classic example of female power and male dominance. ${ }^{23}$ For all their ascribed symbolic significance, Cochiti women are, in Edwin Ardener's terms, a "muted" rather than an "articulate group," excluded from "the dominant communicative system of the society - expressed as it must be through ideology and that 'mode of production' which is articulated with it" (1975: 22). We don't have any say about that are words I have heard from women at Cochiti more times than I can count. However, as Ardener and others have pointed out, in a world in which discourse is controlled by men, women's ideas or models of the world about them finds expression in forms other than direct speech. But, as Ardener also notes, far too few ethnographers have talked to women or deemed their modes of expression worthy of investigation. This is true even in Pueblo studies where, despite the fact that a larger than usual amount of ethnography has been done by women, the overwhelming focus has been on maledominated discourse.

Frank Cushing, who was an iconoclast, and Ruth Bunzel, who was a woman influenced by Boas's insistence on the importance of art, were exceptions to this male bias in their recognition that for generation upon generation of Pueblo women, pottery-making has been a primary and privileged mode of expression. ${ }^{24}$ In Pueblo life, potteries are one of the few forms of "objective culture" that have been identified with and created almost exclusively by women. ${ }^{25}$ Traditionally, men were associated with this mode of production, but excluded from the transformative activities of shaping and firing clay. "In the beginning, Itc'tinaku [Spider Woman] considered how the people should live," and sent her mother and father down to them as "Clay Old Woman and Clay Old Man." Clay Old Woman "began to coil a pot with her 


\section{Barbara A. Babcock}

clay, and Clay Old Man danced beside her singing while she worked" (Benedict 1981: 12). "He" has continued to dance and sing, and "she" has continued to shape the flesh of Mother Earth into ceremonial, utilitarian, and commercial forms, talking to and thanking Grandma Clay at every stage of the creative process.

As archaeologists have demonstrated, as Cushing so finely described in "Zuni Breadstuff," and as the Cochiti story about the origin of pottery I have just quoted reflects, settled Pueblo existence as it developed in the southwestern United States over 2,000 years ago and was lived until the latter part of the nineteenth century was inconceivable without rain, without the cultivation of corn, and without pottery to store water and grain. Clay was not only essential to life but in traditional Pueblo belief was regarded as a living substance. A pottery vessel was not thought of as an inert object but as a "made being," acquiring a kind of conscious and personal existence as it was being made. "As a receptacle for water and food, it held, and was in turn, a source of life" (Hardin 1983: 33), and the designs with which it was painted had "one dominant theme, a prayer for rain for the maturing crops" (Chapman 1950: 6). Moreover, in the Keresan origin myths I have already cited, innumerable forms of life originate as clay images. In addition to the descendents of these clay people that the cacique takes care of, human and animal ceramic figurines are associated, both historically and prehistorically, with the idea of fertility, with agricultural fertility cults, and with rites of human increase.$^{26}$ In this worldview, the creation of babies and the generation of culture are not only compatible, they are inseparable; with both their bodies and their hands, women reproduce the cultural order.

If Pueblo ceramics were once a primary mode of production, they were also and still are symbolic forms, containers of cultural value and models of and for reproduction and regeneration. ${ }^{27}$ Their potteries, like their stories, their rituals, and their kinship system, connect the reproductive aspect of generation with the cultural basis of thought, transmission, and "in a different voice," clay sings. With the encroachment of an Anglo world and the expansion of an Anglo market for Indian objects, pottery-making has become increasingly important as mode of cultural survival and as a cultural voice, a statement of ethnic identity. Potteries are, in Bourdieu's apt phrase, "symbolic capital," for "in a very real way, the survival of the craft symbolizes the survival of the people" (Brody 1976: 76). And, although ceramic scholars have not talked about it in these terms, precisely because it 
is "symbolic capital," Pueblo pottery-making is an institutionalized mechanism for consolidating and preserving female power. ${ }^{28}$

Although women produce these necessary and symbolic vessels, men have traditionally controlled their distribution and marketing, along with other forms of communication with the outside world. This too is reflected in the Cochiti story about the origin of pottery as well as in subsequent ethnographic accounts: after Clay Old Woman shaped the clay, "the old man took the pot and gave a piece of it to everybody in the village" (Benedict 1981: 12). Since at least the fifteenth century, "the exchange of pottery has played a considerable economic role in Rio Grande Pueblo culture" (Snow 1973: 55), and this trading has been the business of men. Matilda Coxe Stevenson recorded the following situation at Zia Pueblo in the late 1880s:

The Sia women labor industriously at the ceramic art as soon as their grain supply becomes reduced, and the men carry the wares to their unfriendly neighbors for trade in exchange for wheat and corn. As long as the Sia can induce the traders through the country to take their pottery they refrain from barter with their Indian neighbors. The women usually dispose of the articles to the traders, but they never venture on expeditions to the Santa Ana and the Jemez. [1894: 11-12]

After 1880, the railroads and the influx of Anglos to the territory created both an expanding "tourist" market for Pueblo pottery and wage-labor jobs for men; women took increasing responsibility for marketing the products of their labor. Predictably, there was resistance to the latter, and as late as 1925, when Chapman, Halseth, and others at the Museum of New Mexico were encouraging pottery "revivals," they discovered that the Santo Domingo Pueblo council did not want Santo Domingo women to take their pottery to the newly instituted Indian Fair in Sante Fe. Acculturation, automobiles, and the advent of an Anglo "art" market that names and wants to know its Indian artists has changed all that. Women still dominate the manufacture of pottery - for example, of approximately two hundred figurative potters in 1984, only twenty are men-but they have also assumed control of its distribution, and have entered into a cash economy and the business of communicating with the outside world-activities that were once their husbands' prerogatives. While Pueblo pottery has continued to be an important vehicle of identity maintenance, it has also become a means of identity change and a crucial variable in the transition from 
a subsistence to a cash economy. ${ }^{29}$ Both the fortunes of this ancient craft in this century and the recent "social drama" centering on pottery at Cochiti support the argument of several students of material culture that the objectual aspects of a culture are both more conservative and more innovative as well as more readily diffused than its behavioral and ideological aspects. ${ }^{30}$

In the remarkable revival of figurative pottery that Helen Cordero's Storyteller has engendered in the last twenty years, women potters have done much more than reshape their traditional roles in terms of economics, mobility, and communication. ${ }^{31}$ By creating not only Storytellers, but Nightcriers, Drummers, Turtles, and other ceremonial and mythic figures, and by exhibiting and demonstrating their art, they have assumed the right to re-present and interpret to the outside world at least some of the aspects of the very discourse in which they are displaced. Both endorsing and challenging men's ideological hegemony, a clay Storyteller is a woman's visual re-creation of a man's verbal and symbolic representations of a woman's biological experience. It is her re-appropriation both of her own symbolic power and his right to articulate it. The very gender ambiguity of Storytellersboth presentational and perceptual-is a statement of competing interests in the terrain of symbolic production. At home, no womens are storytellers, but women are potters and with the transformative power of their hands, they have contrived to tell stories about storytelling, to subvert masculine discursive control, and profoundly to disturb the distribution of power. In this case, the struggle between the powerless and the powerful has been displaced quite literally onto the surface of things. It would seem, in terms of Bauman's reformulation of the distinction between static and dynamic cultures, that the sociocultural system at Cochiti-and probably in other pueblos as well-is changing from a static one "in which rights to signs are derivative from social position" to a dynamic one "in which social position is derivative from the possession of signs" (Bauman 1971: 287).

Helen Cordero and her sisters are manipulating considerably more than clay. They are reproducing "with a difference," and they are figuratively as well as literally playing with fire. Helen teases me a lot, and on one recent occasion, I couldn't resist the temptation to give her a hard time about her fancy new Frigidaire Harvest Gold ice-dispensing refrigerator. She stopped making tortillas, turned from the stove-which she had also just replaced with a new Magic Chef because the old one's self-cleaning oven had ruined the potteries that 
she was preheating before firing them outside in the old way, the right way - and said quite seriously, I'm getting me what I always wanted. And, she has empowered three generations of other Pueblo women to do the same, to reshape their lives and the roles traditionally allotted to them.

Clearly, Evans-Pritchard talked to very different "primitive women" from the ones that I have-if he talked to them at all-and just as clearly the tribal official's attempt to silence them reflects the highly authoritarian nature of Pueblo society and bespeaks a recognition that continuity over time is a political as well as a biological and cultural problem. ${ }^{32}$ Although his motives were reportedly baser, in acting as he did that official was re-asserting the traditional Pueblo male right to mediate with the outside world and protect what he deems sacred discourse as well as attempting to reinvoke an ancient male prerogative to appropriate and control female generativity and creativity. It was, you can almost hear him saying, one thing for old Santiago Quintana to travel to California or to share his culture and its stories with Bandelier and Benedict; it is quite another for his granddaughter to hop a plane in Albuquerque, and to make Storytellers, and to talk about her grandfather and his stories in Denver. Times have changed, and this time he lost his case against the women, but that's another story. . . ${ }^{33}$

\section{Notes}

1. For discussion and documentation of the Storyteller revolution, see Babcock 1983 and Babcock and Monthan 1986.

2. This statement and others that follow in italic type were made by Helen Cordero in conversations between 1978 and 1984 . When we began to work on the story of her life and art, she insisted that she would not spill the beans, and I have not discussed sacred discourse or social and ceremonial organization with her or any other Cochitis. The information about these matters in this essay was obtained from already published accounts by various observers of Cochiti and Keresan life in the past century and from conversations with anthropologists who lived and worked at Cochiti under very different constraints in previous decades.

3. For a general theory of the nature of innovation and the consequences of and conditions for the appearance of novel ideas, see Barnett 1953.

4. Many of these points are made by Judith Modell in her discussion of Zuni Mythology. She argues that Benedict's achievement in this and "other folklore pieces, was to incorporate a notion of imaginativeness into the study of culture" (Modell 1983: 243).

5. Much of my argument, in addition to this statement, is indebted to Roy Wagner's 


\section{Barbara A. Babcock}

stimulating meditation on culture as creativity, as invention in The Invention of Culture (1981).

6. For further discussion of both prehistoric and historic Pueblo figurative pottery traditions, see Babcock and Monthan 1986.

7. For an encyclopedic inventory of Pueblo religion, see Parsons 1939. For discussions of fertility as the root metaphor or master trope of Pueblo culture, see especially Haeberlin 1916, Cushing 1920, and Benedict 1934. See also Black 1984 for an analysis of Hopi corn metaphors.

8. For descriptions of Santiago Quintana, see Benedict's Preface to Tales of the Cochiti Indians (1931: xi) and her letter of 5 September 1925 to Margaret Mead (Mead 1973: 300).

9. In his important essay "Style, Grace, and Information in Primitive Art," Bateson argues that it is probably an error to think of art as being about any one matter other than relationship (1973: 254-55).

10. For discussion of the Pueblo capacity for revitalization, the dynamics of cultural survival, and the importance of art therein, see A. Ortiz 1976 and Brody 1976, 1979. The description of stories as "life for the people" is from the title poem of Leslie Silko's novel Ceremony (1977: 2).

11. The image of a large composite figure covered with smaller versions of itself universally connotes reproduction and, by implication, femaleness. Not surprisingly, Helen's Storytellers have been perceived as female both by Anglo consumers and by Pueblo potters who have imitated her invention. In his suggestive essay "Levels of Communication and Taboo in the Appreciation of Primitive Art," Leach argues that punning, particularly sexual ambiguity, is very common in art forms: "My general proposition is that all true artists tend to devote their principal efforts to themes which contain elements of sensory ambiguity and are subject to taboo. ... When we examine the products of exotic cultures the confusions which first fascinate us are those which have a physiological base, they are the confusions between male and female, between food and not food, between symbols of dominance and symbols of submission" (1973: 230, 234).

12. For discussion of Helen's potteries as autobiographical statements, as shaping and shaped from personal experience, see "Modeled Selves" (Babcock 1985). See Turner 1980 for discussion of social dramas and stories about them.

13. Lange (1968: 232) has this to say about ancestral power: "A fundamental belief in the religious orientation of the Cochiti is that supernatural power is believed to be held by certain individuals at specific times because these powers have been transmitted to cultural predecessors from supernatural beings during various eras of the past. The specific powers vary in accordance with the person's official capacity, or status, and also to the extent to which he is worthy of that status."

14. See especially Fox's discussion of the term yaya ("mother"), which is used both for the cacique and his stone fetish (1967: 143).

15. For transcriptions, summaries, and interpretations of Keresan emergence narratives, see Benedict 1981, Boas 1928, Dumarest 1918, Forde 1930, Parsons 1939, Sebag 1971, Stevenson 1894, Stirling 1942, and White 1932a, 1932b, 1935, 1942, 1962. The motif of creation through the molding of meal, dust, or clay is not limited to origin myths, but is widely found throughout Pueblo narratives.

16. For a very suggestive Jungian analysis of the importance of "chains" of generations, etc., in creation myths as a way of being linked "with historical continuity, i.e., from the inside, with one's ancestral soul, to be connected with the archetype foundations of the psyche, as counter-magic against dissociation," see von Franz 1978.

17. Pueblo "world structure," as a "relentlessly connected universal whole" in which "men, animal, plants, and spirits are intertransposable in a seemingly unbroken chain 


\section{At Home, No Womens Are Storytellers}

of being," constructed in terms of a series of oppositions (A. Ortiz 1972: 143), is something of a structuralist's dream. For a structural analysis of Tewa worldview, see A. Ortiz 1969; of Keres through their creation myths, see Sebag 1971.

18. The position one ascribes to women in Pueblo society depends significantly on whether one focuses on ideology or on praxis. As Bennett and others have remarked, those interpretations (e.g., Benedict) that center on the ideology, which Bennett calls "organic," view Pueblo culture and society as integrated and harmonious. Those (e.g., Goldfrank) who focus on the praxis, which he calls "repressive," emphasize the tension, conflict, and fear of Pueblo life, and the extent to which the individual (male or female) is suppressed and repressed (Bennett 1946:361-74). The truth, I suspect, is somewhere in between, and one must look at the position of women in both ideology and praxis. On the basis of crosscultural evidence, including Alice Schlegel's Hopi work, Peggy Sanday argues (1981: 114) that "female economic and political power is ascribed as a natural right due the female sex when a long-standing magico-religious association between maturity and fertility of the soil associates women with social continuity and the social good." I would respond, not necessarily so, especially not in increasingly acculturated situations which have modified both the social and religious position of women, and certainly not among the Keresan Pueblos.

19. For discussion of the "manly/womanly dichotomy" in terms of which the Keres order their world and of the anthropology of Keres identity, see Miller 1972. See also Austin 1983 for discussion of the relationship between house and kiva.

20. For discussion of Cochiti clans, their curing and nurturant functions, their declining importance, and concomitant changes in Cochiti social organization, see Fox 1967, 1973.

21. In discussing Pueblo attitudes toward innovation in 1949, John Collier observed: "With Christianity, in the Rio Grande Pueblos, came the morality and custom of indissoluble marriage. It was a radical innovation, and apparently was welcomed by the males because it increased their status and power: the men no longer dwelt in the kiva, but lived in his [sic] children's home as co-head of the establishment. The absolute prohibition of divorce became a custom, guarded as such by the officials and priests of the ancient Pueblo religions" (1949: 51). For further crosscultural discussion of the decline in indigenous female power with colonialism, see Sanday 1981: chap. 7.

22. For discussions of Cochiti social and ceremonial organization and changes therein between the early 1920s and the early 1950s, see Goldfrank 1927, Lange 1968, and Fox 1967.

23. Here and elsewhere, I am following Friedl's definition of "male dominance" as "a situation in which men have highly preferential access, although not always exclusive rights, to those activities to which the society accords the greatest value, and the exercise of which permits a measure of control over others" (1975: 7).

24. In particular, see Cushing 1886, 1920, and Bunzel 1972 [1929] for discussion of the meanings, uses, and importance of pottery in Pueblo life.

25. Simmel describes "objective culture" as the world of cultural forms and their artifacts that have become independent of individual human existence. Objective culture is the domain of objects that function as instruments for the cultivation of the person, or as conditions under which he can become a cultural being. He observes that objective culture is overwhelmingly a product of male activity and that, with few exceptions, the artifacts of culture represent the objectification of the male spirit. In his insightful discussion of "Female Culture," and the ways in which female psyche "becomes visible," he notes that "we should expect from women a special interpretation and mode of forming phenomena in the plastic arts" (1984: 6$7,22,83)$.

26. See Parsons 1918, 1919, and 1939 for beliefs and practices associated with rites 


\section{Barbara A. Babcock}

of increase, and the use of clay figures therein. For further discussion, see Babcock and Monthan 1986.

27. Here and elsewhere, I am indebted to Annette Weiner's "model of reproduction," derived in part from Bourdieu, which she has developed in several essays (1978, $1979,1980,1982$ ) and which is based on the premise "that any society must reproduce and regenerate certain elements of value in order for the society to continue... . These elements of value include human beings, social relations, cosmological phenomena such as ancestors, and resources such as land, material objects, names, and body decorations" (1980: 71). Within this model, she distinguishes between "reproduction," referring to cultural attention and meaning given to acts of forming, producing, or creating something new, and "regeneration," referring to the cultural attention and meaning given to the renewal, revival, rebirth, or recreation of entities previously reproduced. More recently, she has formulated the notion of "elementary cycling," by which she means "the cultural configuration of the state of affairs that encompass birth, growth, decay, death, and regeneration.... The life cycle of individuals, now understood as those processes which attach relations and objects to an ego and detach them at other times from other egos, cannot be separated analytically from the societal configuration wherein the natural phenomena of birth, growth, decay, and death are culturally circumscribed.... In this way, the configuration of elementary cycling is the basic logical form out of which integration between the individual and society takes place" (1982: 10). Whatever else it may be, the Storyteller as conceived and created by Helen Cordero is the embodiment of elementary cycling. I am also indebted to Meillassoux's Marxist analysis of precapitalist formation in which he argues that "agricultural self-sustaining formations described here... rely less on the control of the means of material production than on the means of human reproduction: subsistence and women. Their end is reproduction of life as a precondition to production. Their primary concern is to 'grow and multiply' in the biblical sense.... The relations of production are established between 'those who come before' and 'those who come after'" (1972: 100-102).

28. For further crosscultural discussion of institutionalized mechanisms "for consolidating and conserving female power during colonialization," see Sanday 1981: 37 and passim.

29. For further discussion of the value of Pueblo pottery in the transition from a subsistance to a cash economy and the importance of the Acoma pottery-making tradition for women's economic survival, see Reynolds 1986.

30. See, in particular, Barnett 1953, Graburn 1976, and Dawson, Frederickson, and Graburn 1974.

31. For further discussion of the Storyteller revolution and the development and diffusion of this new genre of Pueblo pottery, see Babcock 1983 and Babcock and Monthan 1986.

32. In addition to Weiner 1978, 1979, 1980, see O'Brien 1981, Paige and Paige 1981, and Zelman 1977 for further discussion of the "politics" of reproduction. There is abundant evidence and discussion of the highly authoritarian nature of Pueblo society and the power exerted by the religious hierarchy, but see especially Goldfrank 1945, Ellis 1953, Dozier 1961, and Fox 1973. See also Meillassoux 1972: 100-102 for a Marxist perspective on the politics of reproduction. He argues that in "agricultural self-sustaining formations [which Pueblo society once was] concern for reproduction becomes paramount... [and] reproduction of the unit, both biologically and structurally, is assured through the control of women. ... The shift from production for self-sustenance and self-perpetuation to production for an external market, must necessarily bring a radical transformation, if not the social destruction of the communities." 
33. In conclusion, my thanks to Helen Cordero, who has shared her life and her work with me and changed my life in the process, and to Susan Aiken, with whom I have shared the experience and the interpretation of mutedness. Cochiti Pueblo is not a place where the politics of reproduction are discussed as such, and feminist anthropologists have been rightly cautioned both against projecting our own political concerns and theoretical models onto our analyses of the position of women in other cultures and against using data about women there to buttress arguments about women here. Nonetheless, if we are not attuned to gender dynamics and the politics of discourse in the cultures we are studying, as well as in our own, we will perpetrate such idealistic and projective distortions as the ideas that simpler societies are not contaminated by sexual politics and that potteries and politics have nothing to do with each other. Finally, my apologies for being both unable and unwilling to give a more detailed account of what transpired at the tribal council.

\section{REFERENCES}

Ardener, Edwin. 1975 "Belief and the Problem of Women, and The 'Problem' Revisited.” In Shirley Ardener, ed., Perceiving Women. London: Malaby Press. Pp. 1-27.

Austin, Mary. 1983. The Land of Journey's Ending (1924). Tucson: University of Arizona Press.

Babcock, Barbara A. 1983. "Clay Changes: Helen Cordero and the Pueblo Storyteller." American Indian Art 8, 2: 30-39.

—. 1985. "Modeled Selves: Helen Cordero's 'Little People.'” In E. Bruner and V. Turner, eds., The Anthropology of Experience. Urbana: University of Illinois Press.

Babcock, Barbara A., Guy Monthan, and Doris Monthan. 1986. The Pueblo Storyteller: Development of a Figurative Ceramic Tradition. Tucson: University of Arizona Press.

Bandelier, Adolph F. 1890. The Delight Makers. New York: Dodd, Mead. 1890-92. Final Report of Investigations Among the Indians of the Southwestern United States, Carried on Mainly in the Years from 1880 to 1885 . 2 vols. Papers of the Archaeological Institute of America, American Series 3 and 4. Cambridge, Mass.

Barnett, Homer. 1953. Innovation: The Basis of Cultural Change. New York: McGraw-Hill.

Bateson, Gregory. 1973. "Style, Grace, and Information in Primitive Art." In Anthony Forge, ed., Primitive Art and Society. London: Oxford University Press. Pp. 235-55.

Bauman, Zygmunt. 1971. "Semiotics and the Function of Culture." In Julia Kristeva, J. Rey-Debove, and Donna Jean Umiker, eds., Essays in Semiotics. The Hague: Mouton. Pp. 279-91.

Benedict, Ruth. 1932. "Configurations of Culture in North America." American Anthropologist 34: 1-27.

—. 1933. "Magic." Reprinted in Mead, ed., 1974. Pp. 105-15.

- 1934. Patterns of Culture. Boston: Houghton Mifflin. 
- 1981. Tales of the Cochiti Indians (1931). Albuquerque: University of New Mexico Press.

Bennett, John W. 1946. “The Interpretation of Pueblo Culture: A Question of Values." Southwestern Journal of Anthropology 2, 4: 361-74.

Biebuyck, Daniel, ed. 1969. Tradition and Creativity in Tribal Art. Berkeley: University of California Press.

Black, Mary. 1984. "Maidens and Mothers: An Analysis of Hopi Corn Metaphors." Ethnology 23, 4: 279-88.

Boas, Franz. 1928. Keresan Texts. Publications of the American Ethnological Society, vol. 8.

Bourdieu, Pierre. 1977. Outline of a Theory of Practice. Cambridge: Cambridge University Press.

Brody, J. J. 1976. "The Creative Consumer: Survival, Revival, and Invention in Southwest Indian Arts." In Nelson Graburn, ed., Ethnic and Tourist Arts. Berkeley: University of California Press. Pp. 70-84.

- 1979. "Pueblo Fine Arts." In A. Ortiz, ed., Handbook of North American Indians, vol. 9. Washington: Smithsonian Institution Press. Pp. 603-8.

Bunzel, Ruth. 1972. The Pueblo Potter: A Study of Creative Imagination in Primitive Art (1929). New York: Dover.

Chapman, Kenneth. 1950. Pueblo Indian Pottery of the Post-Spanish Period. Santa Fe: School of American Research.

Collier, John. 1949. Patterns and Ceremonials of the Indians of the Southwest. New York: E. P. Dutton.

Cushing, Frank Hamilton. 1886. "A Study of Pueblo Pottery as Illustrative of Zuni Culture Growth." 4th Annual Report of the Bureau of American Ethnology. Pp. 437-521.

- 1920. "Zuni Breadstuff." Indian Notes and Monographs, vol. 8. New York: Museum of the American Indian.

Dawson, Lawrence E., Vera-Mae Frederickson, and Nelson H. H. Graburn. 1974. Traditions in Transition: Culture Contact and Material Change. Berkeley: Lowie Museum of Anthropology.

d'Azevedo, Warren L., ed. 1973. The Traditional Artist in African Society. Bloomington: Indiana University Press.

Dozier, Edward P. 1961. "Rio Grande Pueblos." In Edward H. Spicer, ed., Perspectives in American Indian Cultural Change. Chicago: University of Chicago Press. Pp. 94-186.

Dumarest, Fr. Noel. 1918. "Notes on Cochiti, New Mexico." Memoirs of the American Anthropological Association, no. 23: 135-236.

Ellis, Florence Hawley. 1953. "Authoritative Control and the Society System in Jemez Pueblo." Southwestern Journal of Anthropology 9: 385-94.

Evans-Pritchard, E. E. 1965. The Position of Women in Primitive Societies and Other Essays in Social Anthropology. New York: Free Press.

Firth, Raymond. 1966. "The Social Framework of Primitive Art." In R. Firth, Elements of Social Organization. Boston: Beacon Press. Pp. 155-92.

Forde, C. Daryll. 1930. “A Creation Myth from Acoma." Folk-Lore 41: 370-87.

Forge, Anthony, ed. 1973. Primitive Art and Society. London: Oxford University Press. 
Fox, Robin. 1967. The Keresan Bridge. New York: Humanities Press.

. 1973. Encounter with Anthropology. New York: Harcourt Brace.

Friedl, Ernestine. 1975. Women and Men: An Anthropologist's View. New York: Holt, Rinehart, and Winston.

Geertz, Clifford. 1976. “Art as a Cultural System.” Modern Language Notes 91, 6: 1473-99.

Goldfrank, Esther. 1927. "The Social and Ceremonial Organization of Cochiti." Memoirs of the American Anthropological Association, no. 33.

- 1945. "Socialization, Personality, and the Structure of Pueblo Society." American Anthropologist 47: 516-39.

Graburn, Nelson H. H., ed. 1976. Ethnic and Tourist Arts. Berkeley: University of California Press.

Haeberlin, H. K. 1916. "The Idea of Fertilization in the Culture of the Pueblo Indians." Memoirs of the American Anthropological Association, no. 3.

Hardin, Margaret Ann. 1983. Gifts of Mother Earth: Ceramics in the Zuni Tradition. Phoenix: The Heard Museum.

Kaufmann, Fritz. 1969. "Art and Phenomenology." In W. Natanson, ed., Essays in Phenomenology. The Hague: Martinus Nijhoff. Pp. 144-56.

Lange, Charles H. 1968. Cochiti: A New Mexico Pueblo, Past and Present. Carbondale: Southern Illinois University Press.

Lange, Charles H., and Carroll L. Riley, eds. 1966. The Southwestern Journals of Adolph F. Bandelier, 1880-1882. Albuquerque: University of New Mexico Press.

- 1970. The Southwestern Journals of Adolph F. Bandelier, 1883-1884. Albuquerque: University of New Mexico Press.

Lange, Charles H., Carroll L. Riley, and Elizabeth M. Lange, eds. 1975. The Southwestern Journals of Adolph F. Bandelier, 1885-1888. Albuquerque: University of New Mexico Press.

Leach, Edmund. 1973. "Levels of Communication and Problems of Taboo in the Appreciation of Primitive Art." In Anthony Forge, ed., Primitive Art and Society. London: Oxford University Press. Pp. 221-34.

Mason, Edith Hart. 1948. "Enemy Bear." The Masterkey 22, 3: 80-85.

Mead, Margaret, ed. 1973. An Anthropologist at Work: Writings of Ruth Benedict. New York: Equinox Books.

—. 1974. Ruth Benedict. New York: Columbia University Press.

Meillassoux, Claude. 1972. "From Reproduction to Production: A Marxist Approach to Economic Anthropology." Economy and Society 1, 1: 93-105.

Merleau-Ponty, Maurice. 1964. "Indirect Language and the Voices of Silence." In M. Merleau-Ponty, Signs. Evanston, Ill.: Northwestern University Press. Pp. 39-83.

Miller, Julius. 1972. “The Anthropology of Keres Indentity.” Ph.D. diss. Rutgers University.

Modell, Judith Schachter. 1983. Ruth Benedict: Patterns of a Life. Philadelphia: University of Pennsylvania Press.

O'Brien, Mary. 1981. The Politics of Reproduction. London: Routledge \& Kegan Paul.

Ortiz, Alfonso. 1969. The Tewa World: Space, Time, Being, and Becoming in a Pueblo Society. Chicago: University of Chicago Press. 
. 1972. "Ritual Drama and the Pueblo World View." In A. Ortiz, ed., New Perspectives on the Pueblo. Albuquerque: University of New Mexico Press. Pp. 135-61.

_. 1976. "The Dynamics of Pueblo Cultural Survival." Paper presented at the American Anthropological Society Meetings, Washington, D.C.

Ortiz, Simon J. 1977. A Good Journey. Berkeley: Turtle Island.

Paige, Karen Ericksen, and Jeffrey M. Paige. 1981. The Politics of Reproductive Ritual. Berkeley: University of California Press.

Parsons, Elsie Clews. 1918. "Nativity Myth at Laguna and Zuni." Journal of American Folklore 31, 120: 256-63.

- 1919. "Increase by Magic: A Zuni Pattern." American Anthropologist 21: 279-86.

- 1939. Pueblo Indian Religion. 4 vols. Chicago: University of Chicago Press.

Reynolds, Terry R. 1986. "Women, Pottery, and Economics at Acoma Pueblo."

In Joan M. Jensen and Darlis A. Miller, eds., New Mexico Women: Intercultural Perspectives. Albuquerque: University of New Mexico Press. Pp. 279-300.

Sanday, Peggy. 1981. Female Power and Male Dominance: On the Origins of Sexual Equality. Cambridge: Cambridge University Press.

Sebag, Lucien. 1971. L'invention du monde chez les indiens pueblos. Paris: François Maspéro.

Silko, Leslie Marmon. 1977. Ceremony. New York: Viking Press.

- 1981. "Language and Literature from a Pueblo Indian Perspective." In Leslie A. Fiedler and Houston A. Baker, Jr., eds., English Literature: Opening Up the Canon. Baltimore: Johns Hopkins University Press. Pp. 54-72.

Simmel, Georg. 1984. On Women, Sexuality, and Love. Trans. with an introduction by Guy Oakes. New Haven: Yale University Press.

Snow, David H. 1973. "Some Economic Considerations of Historic Rio Grande Pueblo Pottery." In A. Schroeder, ed., The Changing Ways of Southwestern Indians: A Historic Perspective. Glorieta, N.M.: Rio Grande Press. Pp. 55-72.

Stevenson, Matilda Coxe. 1894. “The Sia." 11th Annual Report of the Bureau of American Ethnology. Washington: Smithsonian Institution.

Stirling, Matthew. 1942. “Origin Myth of Acoma and Other Records." Bureau of American Ethnology Bulletin, no. 135.

Turner, Victor W. 1980. “Social Dramas and Stories about Them." Critical Inquiry 7, 1: 141-68.

von Franz, Marie-Louise. 1978. Patterns of Creativity Mirrored in Creation Myths. Zurich: Spring Publications.

Wagner, Roy. 1981. The Invention of Culture. Chicago: University of Chicago Press.

Weiner, Annette B. 1978. “The Reproductive Model in Trobriand Society." Mankind 11, 3: 175-86.

- 1979. "Trobriand Kinship from Another View: The Reproductive Power of Women and Men." Man 14, 2:328-48.

- 1980. "Reproduction: A Replacement for Reciprocity." American Ethnologist 7, 1: 71-85.

— 1982. "Sticks and Stones, Threads and Bones: This Is What Kinship Is Made 
Of." Paper presented at the conference on Feminism and Kinship Theory, Bellagio.

White, Leslie A. 1932a. "The Acoma Indians." 47th Annual Report of the Bureau of American Ethnology.

— 1932b. "The Pueblo of San Felipe." Memoirs of the American Anthropological Association, no. 38.

- 1935. "The Pueblo of Santo Domingo." Memoirs of the American Anthropological Association, no. 43.

- 1942. "The Pueblo of Santa Ana." Memoirs of the American Anthropological Association, no. 60.

— 1962. "The Pueblo of Sia." Bulletin of the Bureau of American Ethnology, no. 184.

Zelman, Elizabeth S. 1977. "Reproductive Ritual and Power." American Ethnologist 4, 4: 714-33. 